\title{
LEGAL PRACTITIONERS AS POTENTIAL MONEY LAUNDERERS: BENEFICIAL OWNERSHIP TRANSPARENCY AND PEPS: SOLICITORS REGULATION AUTHORITY $v$ SHARIF (2019)
}

\author{
John Hatchard*
}

Legal practitioners enjoy a high degree of credibility and trust. With this comes vulnerability. For example, a solicitor's trust account may be used by criminals through which to launder their proceeds of crime. ${ }^{1}$ The need to maintain public confidence in the profession remains of paramount importance and it follows that substantial reputational harm can occur where there is a risk that legal practitioners are being used (wittingly or otherwise) to facilitate money laundering.

The January 2019 ruling of the Solicitors Disciplinary Tribunal in Solicitors Regulation Authority (the Applicant) $v$ Sharif (the Respondent) ${ }^{2}$ highlights the care that legal practitioners must take in order to satisfy their anti-money laundering (AML) obligations and the serious consequences of any failure to do so. It also throws light on the use made of the notorious Panama-based law firm Mossack Fonseca in establishing offshore companies as vehicles for purchasing real estate in the United Kingdom (UK) and thus concealing the beneficial ownership of the property. ${ }^{3}$

This note provides a background to the anti-money laundering (AML) obligations of legal practitioners, examines the decision in the Sharif case itself and then discusses some of the key issues raised.

\footnotetext{
Professor of Law, Buckingham Law School, and Co-Director of the University of Buckingham Centre for Extractive Energy Studies.

1 For an interesting discussion, see A Hamman and R Koen, 'Cave Pecuniam: Lawyers as Launderers' [2012] PER 49.

2 Solicitors Regulation Authority v Sharif Case 11805-2018 (Solicitors Disciplinary Tribunal, 2019).

3 It must be emphasised that the establishment of such companies is entirely lawful. As noted below, it is the requirement that a solicitor addresses the risk as to whether such transactions are to be used for money laundering purposes that was in issue in the Sharif case.
} 


\section{LEGAL PRACTITIONERS AS POTENTIAL MONEY LAUNDERERS: BENEFICIAL OWNERSHIP TRANSPARENCY AND PEPS}

\section{THE AML OBLIGATIONS OF LEGAL PRACTITIONERS}

The Financial Action Task Force (FATF) Recommendations ${ }^{4}$ contain a series of well-known money laundering preventive measures. These apply both to financial institutions and to "designated non-financial businesses and professions" (DNFBPs), a term that includes lawyers, notaries and other independent legal professionals. For example, Recommendation 10 requires these bodies to undertake a series of customer due diligence (CDD) measures that include know your customer (KYC) requirements, e.g. verifying the identity of the customer and beneficial owner before or during the course of establishing a business relationship or conducting transactions for occasional customers.

In doing so, the FATF Recommendations emphasise that countries must require financial institutions and DNFBPs to adopt a risk-based approach to mitigate their money laundering and terrorist financing risks. ${ }^{6}$ Politically exposed persons (PEPs) are recognised as posing a heightened money laundering risk. A PEP is defined as:

i. A person who is or has, at any time in the preceding year, been entrusted with a prominent public function by a state other than the UK; an EU institution; or an international body;

ii. An immediate family member of anyone listed in (i) above;

iii. A known close associate of anyone listed in (i) above.

The FATF has noted that 'due to their position and influence, it is recognised that many PEPs are in positions that potentially can be abused for the purposes of committing money laundering offences and related predicate offences, including corruption and bribery'. ${ }^{8}$ Thus when entering or maintaining business relationships with PEPs enhanced due diligence (EDD) measures are required. These are purely preventive in nature and do not 'stigmatise PEPs as being involved in criminal activity'?

4 The FATF is an intergovernmental body with a mandate, inter alia, to set standards for combating money laundering. These are set through the Financial Action Task Force, 'International Standards on Combating Money Laundering and the Financing of Terrorism \& Proliferation' (FATF, 2012, updated 2018) < http://www.fatf-gafi.org/publications/ fatfrecommendations/documents/fatf-recommendations.html> accessed 10 June 2019.

5 Ibid., Recommendation 5.

6 Ibid., Recommendation 1.

7 Money Laundering Regulations 2007, SI 2007/2157, Regulation 14(5).

8 FATF Guidance, Politically Exposed Persons (Paris 2013) p 3.

9 Ibid. 
FATF Recommendation 22(d) states that the CDD and EDD requirements 'apply to lawyers, notaries, other independent legal professionals and accountants when they prepare for or carry out transactions for their client concerning the following activities:

- buying and selling of real estate; ...

- creation, operation or management of legal persons or arrangements, and buying and selling of business entities'. ${ }^{10}$

The reporting of suspicious transactions is a further part of the AML requirements. FATF Recommendation 20 states that 'if a financial institution suspects or has reasonable grounds to suspect that funds are the proceeds of a criminal activity ... it should [must] ${ }^{11}$ be required, by law, to report promptly its suspicions to the financial intelligence unit (FIU)'. ${ }^{12}$ This also applies to DNFBPs and hence legal practitioners. This responsibility is emphasised in FATF Recommendation 23(a) which states that 'Lawyers, notaries and other independent legal professionals should [must] be required to report suspicious transactions when, on behalf of or for a client, they engage in a financial transaction in relation to activities described in paragraph (d) of Recommendation $22^{\prime 13}$ (noted above).

At the time of the time of the proposed transaction in the Sharif case, the FATF requirements were contained in the Money Laundering Regulations 2007 (the ML Regulations) and as regards solicitors, the Solicitors Regulation Authority (SRA) Code of Conduct 2011 and SRA Principles 2011 applied.

\section{THE SHARIF CASE}

Khalid Sharif was a partner in Child \& Child, a London-based firm of solicitors whose specialist practice area was property law. He dealt with the sale and purchase of some of the most expensive properties in London. The firm's client base included a number of high-net worth foreign nationals. Among them were Leyla and Arzu Aliyeva (the sisters) who were the daughters of Ilham Aliyev, the President of Azerbaijan. ${ }^{14}$ These were new clients with whom the firm had had no

\footnotetext{
10 FATF Recommendation 22(d) (n 5).

11 'For the purposes of assessing compliance with the FATF Recommendations, the word should has the same meaning as must'. FATF Recommendations Glossary, emphasis in the original.

12 FATF Recommendation 20 (n 5).

13 Ibid. Recommendation 23.

14 They are referred to as ' $\mathrm{X}$ ' in the ruling. Their identity was revealed in the national
} 


\section{LEGAL PRACTITIONERS AS POTENTIAL MONEY LAUNDERERS: BENEFICIAL OWNERSHIP TRANSPARENCY AND PEPS}

direct contact but who were introduced via an intermediary, Javed Marandi, who was an existing client of the firm. ${ }^{15}$ Given their status, both sisters were foreign PEPs and therefore any business transactions undertaken on their behalf required Mr Sharif to undertake enhanced due diligence. The sisters wished to purchase two flats in Knightsbridge, London for $£ 59.5$ million. To enable them to do so, $\mathrm{Mr}$ Sharif instructed Mossack Fonseca to incorporate a company in the British Virgin Islands (BVI). In January 2015, Exaltation Ltd ${ }^{16}$ was duly incorporated there with the sisters being listed as the beneficial owners. ${ }^{17}$ Exaltation Ltd was the intended purchaser of the Knightsbridge properties. ${ }^{18} \mathrm{Mr}$ Sharif was also the firm's money laundering reporting officer (MLRO). He signed the relevant CDD form in which he confirmed that normal CDD measures had been applied to the proposed transaction and also confirmed on the appropriate form that the sisters were not PEPs.

At the tribunal, Mr Sharif faced several allegations concerning his failure to comply with the relevant AML requirements and that accordingly he had 'failed to behave in a way that maintained the trust the public place in him and in the provision of legal services' ${ }^{19}$ in breach of Principle 6 of the SRA Principles 2011.

The first allegation was that he had failed to take any or any adequate steps to ascertain the status of the sisters as required by the ML Regulations. At the tribunal he did not dispute that his clients were PEPs and admitted that that his failure to undertake adequate checks was a 'clear omission'. ${ }^{20}$ The Tribunal found the allegation proved beyond reasonable doubt.

press: see, for example, Luke Harding, 'Azerbaijan Leader’s Daughters Tried to Buy $£ 60 \mathrm{~m}$ London Home with Offshore Funds' (The Guardian, 21 December 2018) <https://www. theguardian.com/uk-news/2018/dec/21/azerbaijan-leaders-daughters-tried-to-buy-60mlondon-home-with-offshore-funds> accessed 10 June 2019.

${ }^{15}$ Referred to in the Tribunal ruling as Y. Mr Marandi was a close associate of the President of Azerbaijan and therefore, himself a PEP: reported in The Guardian, Ibid.

${ }^{16}$ The company is referred to as ' $\mathrm{E}$ ' in the ruling.

${ }^{17}$ The link is revealed in the Panama Papers: see Offshore Leaks Database, 'Leyla Ilham Qizi Aliyeva' (Offshore Leaks Database, 2019) <https://offshoreleaks.icij.org/ nodes/12119990> accessed 10 June 2019. There is no suggestion in any of the documentation that the purchase monies were the proceeds of crime or that Mr Sharif was knowingly involved in way with money laundering.

${ }^{18}$ After the exchange of contracts on the properties, the sisters reportedly started to pay the purchase price in instalments. They had transferred over $£ 14.3$ million before the Panama Papers revelations in 2016. This led to the sale 'unravelling' after their identity was revealed: see Luke Harding, 'Azerbaijan Leader’s Daughters Tried to Buy £60m London Home with Offshore Funds' (n 15).

19 Solicitors Regulation Authority v Sharif (n 3) para 13.6.

${ }^{20}$ Ibid., para 13.5. 
A second allegation was that he had failed to apply enhanced CDD in respect of the sisters and had thus failed to "maintain the trust the public placed in him and in the provision of legal services. ${ }^{21} \mathrm{Mr}$ Sharif admitted that he had failed to take adequate steps to do so, including by way of making appropriate Internet searches. ${ }^{22}$ The Tribunal found the allegation proved beyond reasonable doubt.

A third allegation was that he had 'failed to take any or any adequate steps to confirm his client's instructions in that he had accepted instructions from Y [Javed Marandi]' ${ }^{23}$ and that 'his actions would not maintain the trust that the public placed in solicitors, and so the Respondent breached [SRA] Principle 6, ${ }^{24}$ At the Tribunal, the Mr Sharif acknowledged that he had exchanged contracts on the property and transferred a considerable sum of money without confirming in writing with the sisters that he was authorised to act on their behalf. The Tribunal found the allegation proved beyond reasonable doubt.

A further allegation was that Mr Sharif had acted in circumstances which disclosed a significant risk that money laundering was taking place and that he had failed both to act with integrity and maintain the trust the public placed in the profession. ${ }^{25}$ It was submitted by the Applicant that the Exaltation transaction presented a higher risk of money laundering on account of a number of warning signs:

- the X clients [the sisters] were new clients with whom the firm had not met, spoken with or corresponded directly;

- the use of one or more intermediaries to give instructions and to provide KYC information;

- the very high value of the transaction;

- the use of a BVI to hold UK property for foreign nationals;

- the use of foreign bank accounts;

- the monies used in the transaction originating from a country about which the respondent knew little. ${ }^{26}$

21 Ibid., para 14.

22 In practice, those seeking to launder their proceeds of crime often seek to conceal their identity: thus often making it extremely difficult to identify them as a PEP. In the Sharif case, the true identity of the sisters was known and this makes the failure of Mr Sharif to identify them as PEPs somewhat puzzling.

23 Solicitors Regulation Authority $v$ Sharif (n 3) para 15.

24 Ibid., para 15.4.

25 This in contravention of Outcome 7.5 of the SRA Code of Conduct and Principles 6 and 7 of the SRA Principles.

26 Solicitors Regulation Authority v Sharif (n 3) para 16.1. 


\section{LEGAL PRACTITIONERS AS POTENTIAL MONEY LAUNDERERS: BENEFICIAL OWNERSHIP TRANSPARENCY AND PEPS}

Mr Sharif admitted he acted in the Exaltation transaction in circumstances where there were grounds to suspect that money laundering may be taking place. ${ }^{27}$ The Tribunal found the allegation proved beyond reasonable doubt.

A further separate matter related to Mr Sharif acting for Mr Marandi who wished to 'gift a London apartment to P2'. ${ }^{28}$ The purchase involved a complex series of transactions. The SRA alleged that the "flat (in an exclusive part of London) was owned by a corporate structure - Company A. Another corporate structure (Company B) was to be created of which P2 would be the ultimate beneficial owner. The shares in Company A would then be gifted to Company B'. ${ }^{29}$ The SRA submitted that this gift presented specific warning signs/risk factors including the fact that the property in question was a high-value gift and was transferred between foreign-owned entities in an offshore jurisdiction. $\mathrm{Mr}$ Sharif admitted that he had failed to conduct ongoing monitoring of his business relationship with Mr Marandi and therefore breached his obligation to undertake enhanced CDD steps. The Tribunal found the allegation proved beyond reasonable doubt.

\section{The Tribunal's Ruling}

The Tribunal found that Mr Sharif was 'wholly culpable for his misconduct' and that 'given the nature of his work, it was even more incumbent on the Respondent to ensure that he complied with the rules and regulatory regime to minimise the risk of money laundering.... The more so in that he was the firm's [money laundering reporting officer] ${ }^{30}$ The Tribunal also noted that there had been significant harm to the reputation of the profession in that Mr Sharif's failings had led to a risk of large amounts of money being laundered. ${ }^{31}$ This misconduct was aggravated in that 'he ought to have known that he was in material breach of his obligation to protect the public and the reputation of the profession'. ${ }^{32}$ However, mitigating factors, including the fact that he had cooperated with the investigation and that no client had suffered any loss, meant that the misconduct was not so serious as to

27 Ibid., para 16.6.

28 Identified in the press as Mirjalal Pashayev who is a cousin of Azerbaijan's first lady and Vice-President Mehriban Aliyeva. It seems to have been assumed at the Tribunal that she was also a PEP.

29 Solicitors Regulation Authority v Sharif (n 3) para 17.1.

30 Ibid., para 31.

31 Ibid., para 32.

32 Ibid., para 32. 
require his removal from practice. Mr Sharif was fined $£ 45,000$ with agreed costs of $£ 40,000$.

\section{SOME COMMENTS}

\section{The Panama Papers and Beneficial Ownership Transparency}

The Panama Papers leak in 2016 revealed the role of Mossack Fonseca in establishing complex offshore corporate structures for PEPs (among others), with the British Virgin Islands (a British Overseas Territory (BOT)) being particularly popular as the place of incorporation. Seemingly it was only as a consequence of the release of the Panama papers, that the link between the Aliyeva sisters, Exaltation Ltd and Child \& Child was revealed.

The Sharif case is seemingly the first in which a UK-based legal practitioner has been penalised as a result of the publication of the Panama Papers. It demonstrates the manner in which PEPs (often assisted by their legal representatives) use offshore companies to purchase real estate in the UK and thus seek to conceal their beneficial ownership of the property. ${ }^{33}$ In fact, in mitigation it was asserted on Mr Sharif's behalf that 'There was nothing uncommon about the use of a corporate structure for the purchase and sale of property in Knightsbridge; on the contrary, it was prolific'. Further, as regards the Marandi gift: 'There was nothing unusual in the nature of the transaction; a transfer using corporate structures was the obvious way to effect the transaction'. ${ }^{34}$ The scale of such activity was emphasised in 2019 when Global Witness reported that 'over 87,000 properties in England and Wales valued at an excess of US $\$ 132.4$ billion ( $£ 100$ billion) are owned by anonymous companies registered in tax havens'. ${ }^{35}$

The Sharif case highlights the need for global action to require transparency in the beneficial ownership of such companies. In 2015, the UK became the first

\footnotetext{
33 See OCCRP, 'Report: US\$132 Billion of UK Property is Registered in Tax Havens' (OCCRP, 18 March 2019) <https://www.occrp.org/en/daily/9397-report-us-132-billion-ofuk-property-is-registered-in-tax-havens $>$ accessed 28 March 2019. See also Transparency International UK, Corruption on your doorstep: How corrupt capital is used to buy property in the UK (Transparency International UK, London 2014) <https://www. transparency.org.uk/publications/corruption-on-your-doorstep/> accessed 10 June 2019.

34 Solicitors Regulation Authority v Sharif (n 3) paras 21, 26.

35 In fact, HM Land Registry has a publicly available data of overseas companies ownership: see HM Land Registry, 'HM Land Registry: Overseas Companies Ownership Data' (GOV.UK, 7 November 2017) <www.gov.uk/guidance/hm-land-registry-overseascompanies-ownership-data> accessed 2 April 2019.
} 


\section{LEGAL PRACTITIONERS AS POTENTIAL MONEY LAUNDERERS: BENEFICIAL OWNERSHIP TRANSPARENCY AND PEPS}

G20 country to introduce a public registry of beneficial ownership with companies being required to keep a register of people with 'significant control over the company'. ${ }^{36}$ Given their significance as offshore 'secrecy jurisdictions' the requirement contained in the Sanctions and Money Laundering Act 2018 that the BVI and other BOTs introduce their own public beneficial ownership registers is particularly noteworthy. Indeed by 2023 , all BOTs Territories will be expected to have public beneficial ownership registers in place 'in line with the UK Government's global campaign to make public registers the global norm by then'. ${ }^{37}$ It will be interesting to see whether the type of transaction undertaken in the Sharif case remains so prolific thereafter or whether they are simply moved to other secrecy jurisdictions.

\section{Taking AML Obligations Seriously}

It is important to emphasise that establishing an offshore company is entirely lawful, as is using a company to purchase real estate in the UK. It is the mirroring of such legitimate transactions by money launderers that makes the offence so difficult to detect and investigate. Given their role in real estate and other property transactions, legal practitioners remain vulnerable to facilitating money laundering by their clients. The Sharif case serves as a stern reminder to all legal practitioners of the need to be proactive in satisfying their AML obligations.

This point is emphasised in a 2017 Transparency International report which highlighted the very low number of suspicious activity reports being made by legal practitioners. ${ }^{38}$ This is reinforced in the 2018 Suspicious Activity Reports (SARs) Annual Report from the National Crime Agency which notes that a record number of 463,938 SARs were made to the UK Financial Intelligence Unit between April

\footnotetext{
36 See Small Business, Enterprise and Employment Act 2015, s 81.

37 See Sir Alan Duncan's answer to Written Question 211611 dated 23 January 2019 asked by Dame Margaret Hodge: Sir Alan Duncan, 'British Overseas Territories: Companies' (UK Parliament, 28 January 2019) <https://beta.parliament.uk/questions/eUPACHFA> accessed 10 June 2019. See further John Hatchard, 'Money Laundering, Public Beneficial Ownership Registers and the British Overseas Territories: The Impact of the Sanctions and Money Laundering Act 2018' (2018) 30(1) Denning Law Journal 185.

38 See Transparency International UK, 'Don't Look, Won't Find: Weaknesses in the Supervision of the UK's Anti-Money Laundering Rules' (Transparency International UK, November 2015) <https://www.transparency.org.uk/publications/dont-look-wont-findweaknesses-in-the-supervision-of-the-uks-anti-money-laundering-rules/> accessed 10 June 2019, esp pp 12-13.
} 
2017 and March 2018. ${ }^{39}$ However, just 2,660 (0.57\%) were made by 'independent legal professionals' and this was $11.92 \%$ lower than the previous year. ${ }^{40}$ As the report notes, the 'UKFIU makes no comment as to the relative volume of reports from different sectors. It is for the sectors and their supervisors to assess if the volume of SARs submitted is proportionate to the risks their sectors face'. ${ }^{4}$

Perhaps it is no coincidence that in March 2019, the Solicitors Regulation Authority announced that it intended to carry out spot checks of 400 law firms to ensure they were not breaching their AML obligations and warned that firms would face an enforcement process and significant penalties if they had failed to do so. ${ }^{42}$

\section{CONCLUSION}

The Sharif case highlights the vulnerability of legal practitioners to involvement in money laundering and the crucial importance that they satisfy all their AML responsibilities with a failure to do so leading to serious consequences. Further, given the limited number of suspicious activity reports being made by legal practitioners to the UK Financial Intelligence Unit, the case may well provide a wake-up call for other practitioners to take effective steps to fulfil their AML obligations.

While there was no suggestion of any attempt to launder the proceeds of crime in the Sharif case, it also highlights the manner in which companies incorporated in offshore jurisdictions are used to conceal beneficial ownership and the risk that these can be used to facilitate money laundering. This highlights the importance of the developing strategies requiring all states to adopt public beneficial ownership registers. Here the ongoing work of the UK Government is commendable.

\footnotetext{
39 National Crime Agency, 'Suspicious Activity Reports (SARs) Annual Report 2018' (National Crime Agency, 2018) <https://nationalcrimeagency.gov.uk/who-we-are/ publications/256-2018-sars-annual-report/file> accessed 10 June 2019, p 2.

40 Ibid., p 6.

41 Transparency International UK (n 38) p 6.

42 The Times, 'Firms face random money laundering checks' (The Times, 20 March 2019) $<$ https://www.thetimes.co.uk/article/firms-face-random-money-laundering-checksqqssfnlqr> accessed 10 June 2019.
} 